\title{
MORPHOANATOMY OF Myracrodruon urundeuva FR. ALL. SEEDLINGS SUBMITTED TO DIFFERENT LEVELS OF WATER IN THE SOIL
}

\author{
MORFOANATOMIA DE PLÂNTULAS DE Myracrodruon urundeuva FR. ALL. \\ SUBMETIDAS A DIFERENTES NÍVEIS DE ÁGUA
}

\author{
Givanildo Zildo da SILVA ${ }^{1}$; Riselane de Lucena Alcântara BRUNO $^{2}$; \\ Cibele Chalita MARTINS ${ }^{3}$; Aderdilânia Iane Barbosa de AZEVEDO ${ }^{4}$; \\ Camila Firmino de AZEVEDO ${ }^{5}$; Rivete Silva LIMA ${ }^{6}$
}

1. Engenheiro Agrônomo, Doutorando, Faculdade de Ciências Agrárias e Veterinárias, Universidade Estadual Paulista - Unesp, Jaboticabal, SP, Brasil. givanildozildo@ hotmail.com; 2. Engenheira Agrônoma, Professora, Doutora em Agronomia, Universidade Federal da Paraíba, Areia, PB, Brasil; 3. Engenheira Agrônoma, Professora Livre-Docente, Faculdade de Ciências Agrárias e Veterinárias - Unesp, Jaboticabal, SP, Brasil; 4. Bióloga, Doutoranda, Universidade Federal da Paraíba, Areia, PB, Brasil; 5. Bióloga, Professora, Doutora, Universidade Estadual da Paraíba, Centro de Ciências Agrárias e Ambientais, Lagoa Seca, PB, Brazil; 6. Biólogo, Professor Associado III, Universidade Federal da Paraíba, Centro de Ciências Exatas e da Natureza - Campus I, Departamento de Sistemática e Ecologia, João Pessoa, PB, Brazil.

\begin{abstract}
Myracrodruon urundeuva Fr. All. is a medicinal plant of the Caatinga biome, in brazilian northeast. This region is characterized by prolonged dry periods but little is known about the plants mechanisms to tolerate low water availability during their initial phase of growth and establishment seedling. The objective of this project was to evaluate morphological and anatomic characteristics of $M$. urundeuva seedlings submitted to different water levels in the soil. In a first experiment, the diaspores were sown in trays containing soil taken from the place of occurrence of the species. The substratum was moistened with water to reach 10 to $60 \%$ of the soil water retention capacity, with $5 \%$ intervals. In a second experiment, the diaspores were sown in the substratum kept at $60 \%$ of its water retention capacity for 15 days for the total seedling emergence since this is the most favorable condition for the species as identified during the first phase of this experiment. After that period, plant watering was suspended and the seedling kept in substrata at 60, 30, $25,20,15$, and $10 \%$ of their water holding capacity for an additional period of 10 days, both experiments performed in protected environment. The increasing reduction in water availability led to a reduction in the number of leaves, the leaf area and leaflet thickness, the number of stomata in the leaf and in the cotyledon, the root length and the diameter of the central root. Characteristics such as the stem length, length, width and thickness of the cotyledon were not modified by the hydric stress.
\end{abstract}

KEYWORDS: Caatinga. Hydric stress. Medicinal plant.

\section{INTRODUCTION}

The naturally occurring population of Myracrodruon urundeuva Fr. All has been decreasing steadily in the last decade due to the use people give to compounds found in its bark as anteinflammatory products. The roots are used to treat rheumatism problems and the leaves are indicated to treat stomach ulcer (ALMEIDA et al., 2005; OLIVEIRA et al., 2007; SOUZA et al., 2007; MARIANO et al., 2009; PAES et al., 2009; CARLINI et al., 2010).

The morphology, the physiology and the ecology of plants of the "Caatinga" are typical of the characteristics of the biome since they are species adapted to high temperatures and low rain fall. To understand the relations between the plants and the environmental factors is of fundamental importance for the development of strategies for the conservation and management of natural habitats (COSTA et al., 2010; JAFARIAN et al., 2011).
The morpho-anatomical characterization of seedlings has an outstanding role in the research of species of arid and semiarid environments providing important information on the development of species, subsidizing the production of seedlings and allowing a better comprehension of plant establishment processes under natural conditions (GUERRA et al., 2006). In addition to that, those evaluations give support to the interpretations of laboratory tests, the recognition of species in soil seed banks and demonstrate the effects that the environmental factors have on those individuals beyond helping to understand the survival mechanisms of those species under field conditions (NERY et al., 2007).

One of the techniques used in laboratory to simulate conditions of low moisture substrata on the germination of seeds of arboreal species has been the use of aqueous solutions with different osmotic potentials (MARTINS et al., 2011; MARTINS et al., 2014). But, the gravimetric method by the 
measurement of the soil water retention capacity is the nearest to what really occurs in the field (SOUZA et al., 2000; REICHARDT; TIMM, 2012). This method has been used with good results in projects to measure the growth of Hymenaea courbaril L. (NASCIMENTO et al., 2011) and Guazuma ulmifolia Lam. (SCALON et al., 2011) seedlings under different levels of water in the soil.

Figueirôa et al. (2004) evaluated the growth of 30 and 60 day old $M$. urundeuva seedlings which had been transplanted from sand substratum when they were 11 days old. Although the importance of the final establishment of the seedlings, the daily observations of the initial stages is also very important, mainly in semiarid environments, since this is the most susceptible period in the plant life and this species displays little recruiting of young plants in the field (KILL et al., 2012).

Thus, the objective of this project was to evaluate morphologic and anatomical characteristics of $M$. urundeuva seedlings growing in different levels of water availability in the soil.

\section{MATERIAL AND METHODS}

The present work made use of diaspores harvested from ten $M$. urundeuva matrix trees growing in the municipality of "Boa Vista", state of Paraíba, Brazil $\left(7^{\circ} 15{ }^{\prime} 34^{\prime}\right.$ S e $\left.36^{\circ} 14^{\prime} 24^{\prime \prime} W\right)$. At the same time, samples of the soil of the loci were taken at depths between 0 and $10 \mathrm{~cm}$. The soil and the diaspores were sent to the Seed Analysis Laboratory of the Field Production and Environmental Sciences Department of the Federal University of Paraiba, municipal district of Areia, Paraiba State, Brazil. The diaspores were submitted to cleaning and wing removal and then placed inside Kraft paper bags and stored in a cold chamber $\left(13 \pm 2{ }^{\circ} \mathrm{C}\right.$ and $\mathrm{RH}$ of $\left.65 \%\right)$ for four months. At the moment the experiments started, the diaspores water content was of $10.8 \%$.

The soil was analised and had a frank sandy texture, porosity of $425.8 \mathrm{~g} . \mathrm{Kg}^{-1}$; sand, silt, and clay of 672,$2 ; 240,2$ and $87,6 \mathrm{~g} . \mathrm{Kg}^{-1}$, respectively, soil and particle densities of 1,51 and $2,63 \mathrm{~g} . \mathrm{cm}^{-1} ; \mathrm{pH}=$ 6,63; P = 2,60 mg. $\mathrm{dm}^{-3} ; \mathrm{Na}^{+}=0,31 \mathrm{cmolc} \cdot \mathrm{dm}^{-3} ; \mathrm{K}^{+}=$ 0,51 cmolc. $\cdot \mathrm{dm}^{-3} ; \mathrm{Ca}^{++}=2,94$ cmolc. $\mathrm{dm}^{-3} ; \mathrm{Mg}^{++}=$ 3,31 cmolc. $\mathrm{dm}^{-3}, \mathrm{Al}^{+++}=0,00$ cmolc. $\mathrm{dm}^{-3}, \mathrm{~N}=0,70$ g. $\mathrm{Kg}^{-1}$ and organic matter $=12,6 \mathrm{~g} \cdot \mathrm{Kg}^{-1}$. To remove little stones and gravel it pass through screens and then was dried under room conditions till it reached a constant weight $(2 \%)$.

To determine the water retention curve, first field capacity was determined by the direct gravimetric method starting with five tubes, each one containing $1 \mathrm{Kg}$ of water saturated soil by capillarity. After that, the soil was submitted to drainage for more than 24 hours till the process stopped naturally. The water levels in the substratum were determined by calculating the amount of water retained by the soil after the drainage process and subtracting the soil initial moisture (SOUZA et al., 2000; REICHARDT; TIMM, 2012).

In a first experiment, the diaspores were homogenized and disinfested with sodium hypochlorite at $0.5 \%$ for five minutes. After that, they were sown at a depth of $1 \mathrm{~cm}$ in plastic trays (29 X 21 X $6 \mathrm{~cm}$ ) containing $1 \mathrm{Kg}$ of soil which were moistened at the following levels of saturation: $60,55,50,45,40,35,30,25,20,15$, and $10 \%$. The trays were kept in protected environment $\left(26 \pm 5{ }^{\circ} \mathrm{C}\right.$ and $68 \%$ of $\mathrm{RH}$ ). Soil water levels were maintained by means of daily weighing and repositioning water when necessary. Each water level was represented by five trays (replications) and each one sown with 25 diaspores.

In the second experiment, the diaspores were kept at the soil water retention capacity of $60 \%$ up to the $15^{\text {th }}$ day after sowing. After that, the trays were no longer irrigated till the capacities of 30,25 , 20 , 15, and $10 \%$ of water level in the soil were reached. The check treatment was that in which the soil was kept at $60 \%$ of the soil water holding capacity. So, the total number of treatments was of six.

The $M$. urundeuva normal seedlings were evaluated 25 days after sowing and they were sampled as representative of each treatment (BRASIL, 2013).

The morphological analyses were carried out with five replications of 10 individuals each with a total of 50 seedlings per evaluated treatment. For the anatomical analyses, four seedlings were used in which each one represented a replication and calculated by the mean of five measures of the sections of the same seedling. In both experiments, the morphological and anatomical characteristics submitted to evaluation were the following: number of leaves, length and width the primary leaf, length, width and thickness of the terminal leaflet, length and thickness of the cotyledon, length and diameter of the stem, length and thickness of the cotyledon, number of stomata in the leaves and cotyledon, stem length and diameter, root length and diameter of the root central cylinder. The evaluated organs are indicated in Figure 1. 


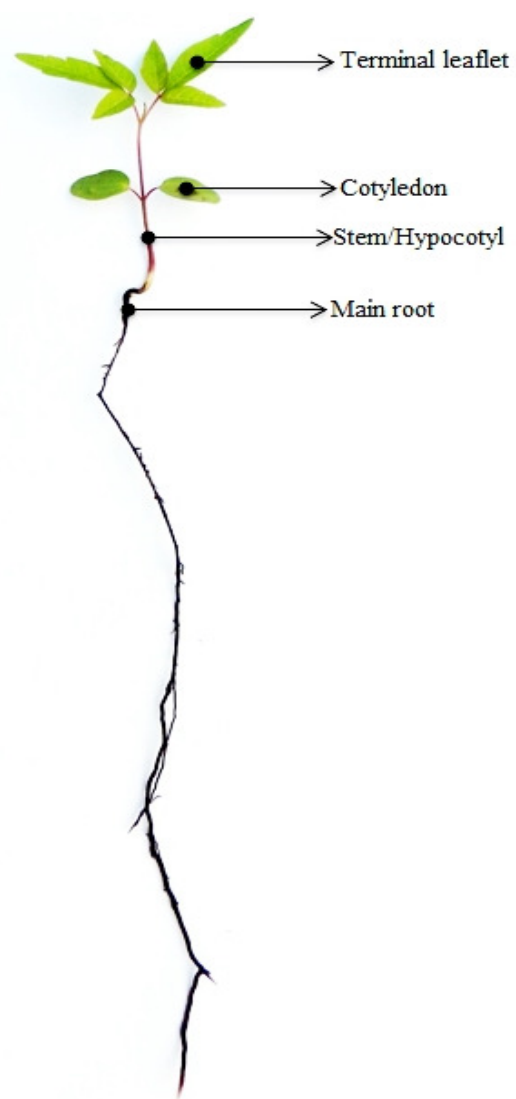

Figure 1. Localization of the sections and measurements of each organ in M. urundeuva seedlings 25 days after seeds sowing.

The descriptions of the morphological study were made with the help of a binocular stereomicroscope, digital photographic chamber, a digital caliper, and a common rule. The measurements of width, thickness, and diameter were taken at the median region of the organ, except in the case of roots which were measured $2 \mathrm{~mm}$ below the transition zone. Length was measured according to each organ: the first leaf and the central leaflet were measured from the petiole base up to the apex; the cotyledon from the base to the apex; the stem, from the colon up to the cotyledons; the root, from the cowl up to the colon (AZEVEDO et al., 2014).

For the anatomical analysis, the sampled seedlings were fixed in FAA $70 \quad(5 \%$ of formaldehyde, $5 \%$ of acetic acid and $90 \%$ of ethanol $70 \%$ ) and included in paraffin (JOHANSEN, 1940). With the help of a rotation microtome, the seedlings were submitted to histological transversal sections resulting in $5 \mu \mathrm{m}$ thick segments of the cotyledon median section, of the central leaflet, of the hypocotyl and root. These samples were dyed with safrablue in an aqueous solution and fixed in a permanent fashion in slides with the help of the synthetic resin (KRAUS; ARDUIN, 1997, modified).
For the visualization and counting of the stomata, paradermic sections in both faces of the median region of the central leaflet and cotyledon were made. The sectioning was manually made with a steel slide and the cuttings were clarified in sodium hypochlorite at $1 \%$ and then stained with blue methylene at $10 \%$; the sections were then mounted on semi-permanent slides with glycerin (KRAUS; ARDUIN, 1997). The counts of stomata were made on paradermic sections of the abaxial face of the leaflet and cotyledon because it is of the hypostomatic type, with the resulting stomata density of $200 \mu^{2}$.

The slides with histologic sections were analyzed in an optical microscope and the photographic register made with an camera coupled to the program of digital images capture Ks- 400 .

The treatment replications were distributed according to a completely random design, with five replications for the morphological characteristics and four, for the anatomic ones.The results were firstly tested for normality (Shapiro-Wilk test) and homoscedasticity (Cochran test), submitted to ANOVA and polynomial regression models. 


\section{RESULTS AND DISCUSSION}

All the water levels in the soil caused significant responses $(\mathrm{p} \leq 0.01)$ in $M$. urundeuva plants leaf area (Figure 2). The maximum leaf development was verified under water availability in the substratum between 50 and $58 \%$ of the soil water retention capacity. Similar results with Eugenia pyriformis Cambess. (SCALON; JEROMINE, 2013) and $H$. courbaril (NASCIMENTO et al., 2011) were reported.
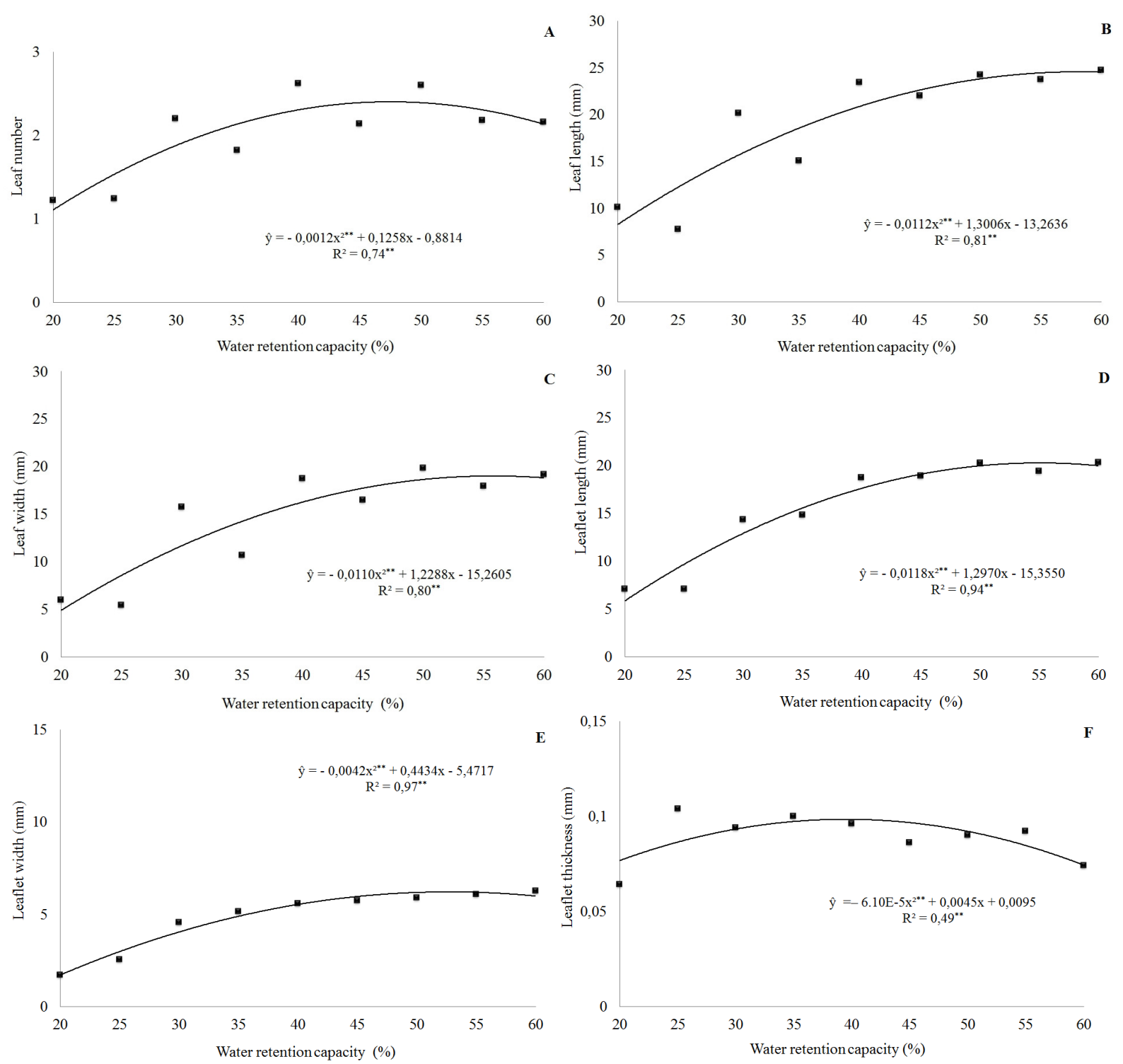

Figure 2. Number (A), length (B) and width (C) of the leaf, length (D), width (E), and thickness (F) of the leaflet of M. urundeuva seedlings growing in different levels of water in the soil.

Among the factors stressing plant growth in the Caatinga biome, water availability is the one taking place in all plant developmental phases - it is responsible for alterations in all biochemical and morphological processes. Under hydric stress conditions, reductions in leaf number, leaf and leaflet area of $M$. urundeuva seedlings were verified to occur (Figure 2). When the water level dropped to 10 to $15 \%$ of the soil water retention capacity, seedling emergence occurred no longer. The reduction in the number of leaves and size of leaflets is thought to be a survival mechanism to permit the conservation of water in the plants during dry periods to avoid the dehydration of the plants by transpiration (SILVA et al., 2011; SOUSA NETO et al., 2011).

Reduction in leaf area is a precocious plant response to hydric stress - as a consequence of the lesser availability of water, the plant cells expand less and this causes a reduction in transpiration (TAIZ; ZEIGER, 2013). The lack of water in the soil is a limiting factor for the growth of plant 
species, thus the water deficit in several parts of the world can cause a reduction of productivity in large crops (LECHINOSKI et al., 2007) and the perpetuation of forest species in arid and semiarid biomes, such as is the case of $M$. urundeuva. Leaf area reduction was also reported in the production of G. ulmifolia (SCALON et al., 2011) such as reductions of the photosynthetic rate in $M$. urundeuva under conditions of hydric deficit (MARIANO et al., 2009)

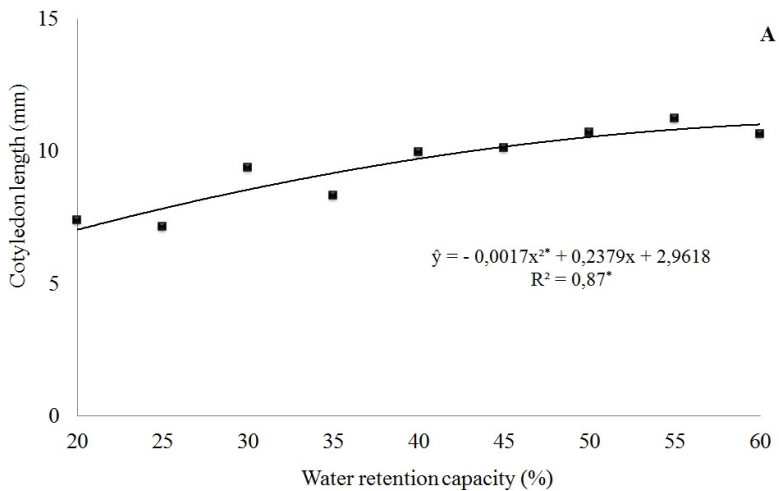

The evaluation of the cotyledons showed that increasing water availability brought about an increment in their area (Figura 3), although thickness was not altered. The photosynthetic cotyledons did not drop from the seedlings up to 25 days after sowing. According to Figueirôa et al. (2004), this characteristic contributes to plants survival in their natural habitat - they represent strategic advantages for species growing in open environments, since they permit a rapid initial growth, little dependent on seed reserves.

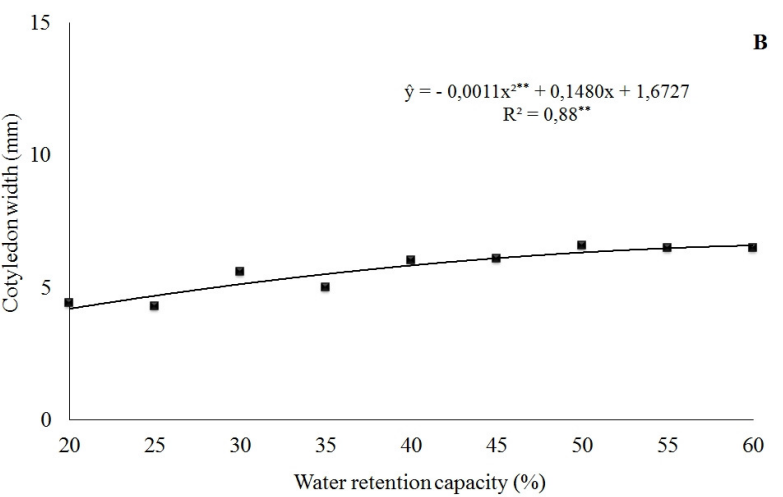

Figure 3. Cotyledon length (A) and width (B) of M. urundeuva seedlings growing in different soil water levels.

Considering the front view of the leaflet and cotyledons of $M$. urundeuva, it is possible to see that the epidermis cells show a wavy contour and anomocytic stomata on both faces although less frequent on the adaxial surface, the reason why they are evaluated on the abaxial face (Figure 4). These characteristics were similarly described in $M$. urundeuva and Schinus terebinthifolius Raddi (DUARTE et al., 2009).
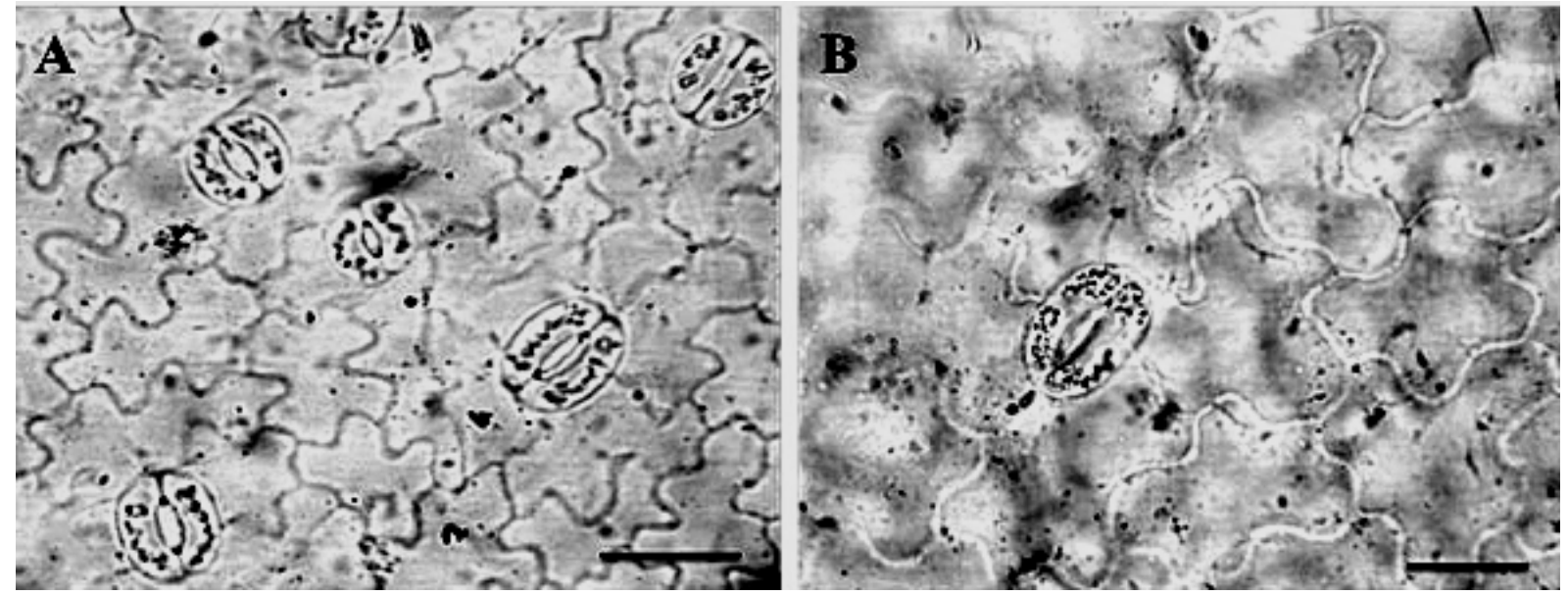

Figure 4. Paradermic sections on the abaxial face of leaflets (A) and cotyledon (B) of M. urundeuva seedlings (scale $-5 \mu \mathrm{m})$.

The leaf stomata density (Figure 5A) was verified to increase with the increase in water availability in the soil. Little variation was observed in cotyledon stomata density (Figure $5 \mathrm{~B}$ ); the increments were observable only after water in the soil reached levels above $45 \%$ of the soil water retention capacity. This is thought to be a strategy to avoid water loss although keeping the photosynthetic apparatus of both evaluated organs under hydric stress. Mariano et al. (2009) reported similar results for leaves under that condition. So, reductions in leaf area and in the number of stomata resulting from water levels lower than the soil water retention capacity are probably $M$. urundeuva 
seedlings adaptive characteristics to hydric stress conditions which usually take place in the semiarid environment of the brasilian northeastern.
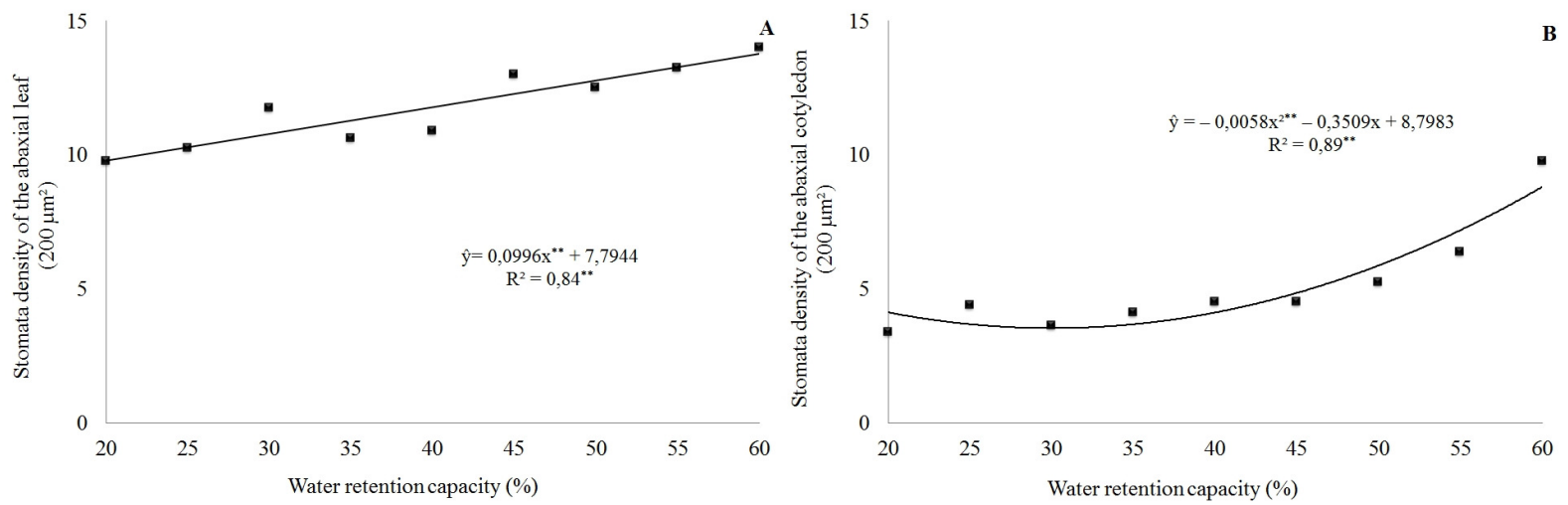

Figure 5. Stomata density of the abaxial leaf (A) and the cotyledon (B) of M. urundeuva seedlings growing in different water levels.

When the stem (hypocotyl) length is analyzed, it is seen that the treatments caused them to be no significantly different one from the other, with a general mean of $1.91 \mathrm{~mm}$ and a range of 1.8 to $2 \mathrm{~mm}$; on the other hand, the main root central cylinder length and diameter were directly proportional to water availability (Figure 6A and C). The stem diameter reached its maximum value (1.35 $\mathrm{mm}$ ) when the capacity was of $42 \%$ (Figure 6B).
This fact emphasizes that the roots of $M$. urundeuva seedlings, when under different levels of water availability, grow better when under conditions of higher water availability whereas the initial growth of the seedling stem is not affected by water variation in the soil. This was also reported by Figueirôa et al. (2004), in a research work with the same specie.

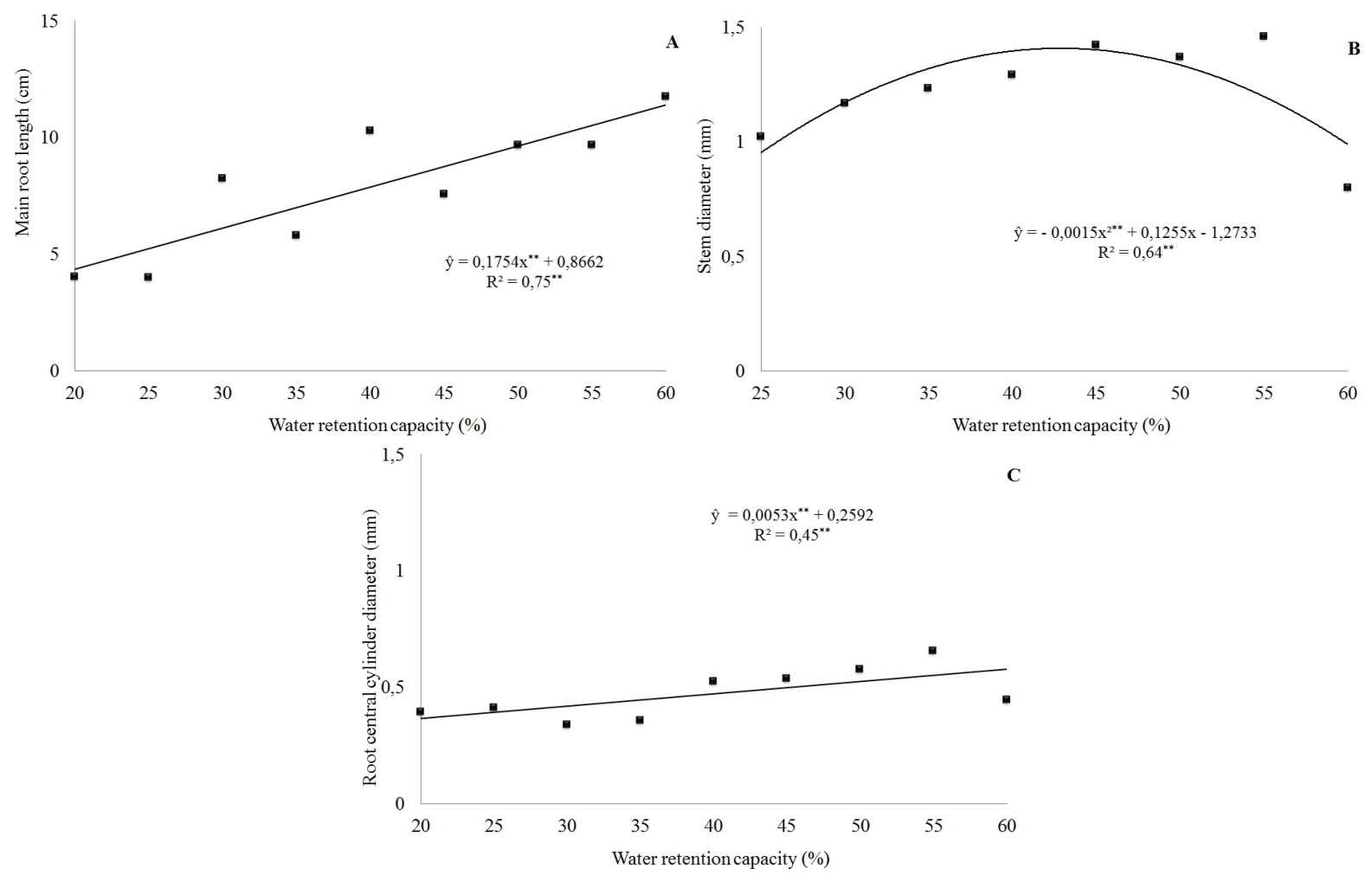

Figure 6. Main root length (A), stem diameter (B), and root central cylinder diameter (C) of Myracrodruon urundeuva seedlings growing in different levels of water in the soil.

When the seedlings growing under hydric stress conditions were examined, it was seen that most of the modifications caused by that stress were found to occur in the leaves (Figure 7). However, 
the satisfactory development morpho-anatomical, that is formation of normal seedlings $M$. urundeuva, at different levels of the retention capacity (of 20-
$60 \%$ ) is a mechanism of adaptation to hydric stress in semiarid conditions.
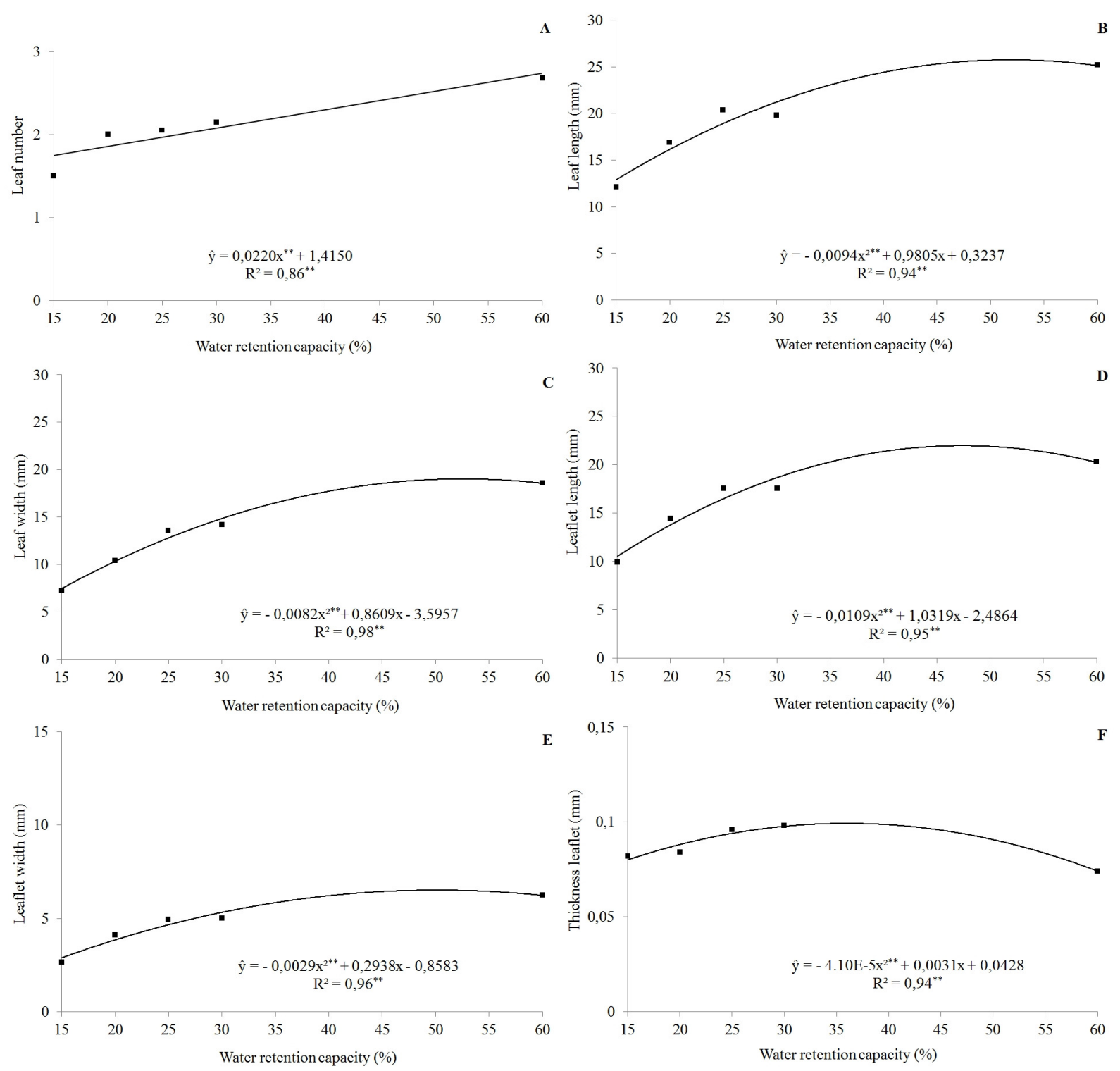

Figura 7. Number (A), length (B) and width (C) of the leaf, length (D), width (E), and thickness (F) of the leaflet of M. urundeuva seedlings developed under hydric stress condition and 15 days after being transferred to ideal water level in the soil.

The structural variations caused by environmental factors are strongly expressed in the morphology and anatomy of the leaves (DICKSON, 2000); that is the reason why the leaf is considered the most variable organ in the plant and has historically been used as an indicator of environmental conditions. He also points that those foliar adaptations show the narrow relationship between anatomy and the efficiency of physiological processes such as transpiration/photosynthesis.

Leaf number increases linearly with increments in water level in the soil (Figure 7A).
Lowering the water level in the soil leads to reductions in leaf area as shown by the measurements of leaf and leaflet thickness (Figures 7B and E) and leaflet thickness (Figure 7F) what shows the phenotypic adaptation of the $M$. urundeuva leaves to the water content in the soil. These adaptations do not demand genetic variation and are, also, reversible (TAIZ; ZEIGER, 2013) in this particular case when the soil reach ideal moisture conditions.

McCree and Fernandez (1989) and Munns (2002) explain that one of the most obvious responses of plants to water deficit consists in 
decreasing the production of the leaf area. It is however, a means of maintaining photosynthesis with less water loss by transpiration.

For the other morphological characteristics evaluated after hydric stress, only main root length and the root central cylinder diameter were influenced by the lower level of water in the soil (Figure 8).

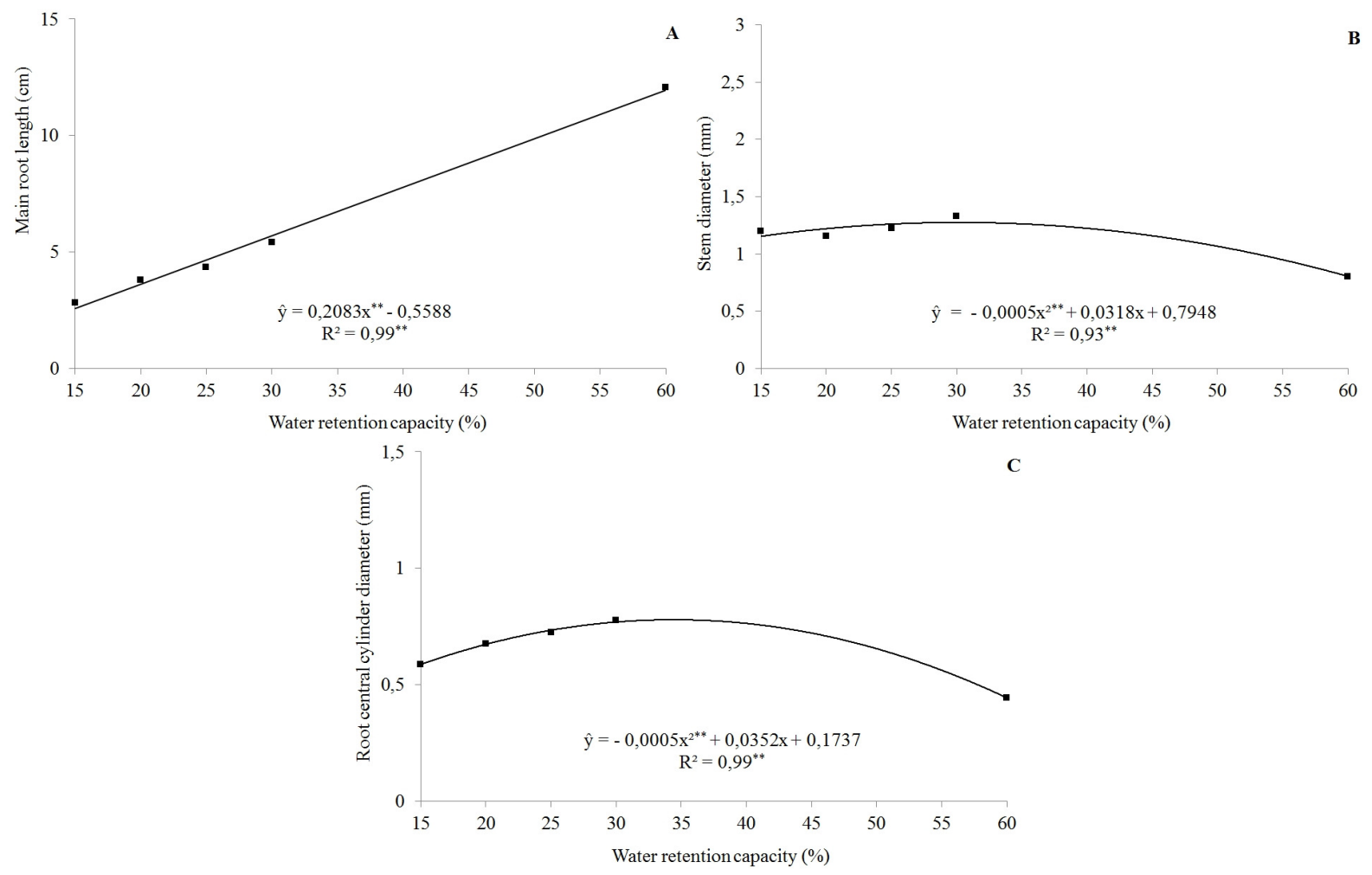

Figura 8. Main root length (A), stem diameter (B), and the root central cylinder diameter (C) of M. urundeuva seedlings developed under hydric stress condition and 15 days after being transferred to ideal water level in the soil.

The different levels of water in the soil led to alterations in root length (Figure 8A) with the data adjusting to the linear model and the maximum length $(12.08 \mathrm{~cm})$ being reached when soil moisture reached $60 \%$ of its total water retention capacity. When soil moisture was of $15 \%$, the value $(2.82 \mathrm{~cm})$ was significantly lower than that of the check treatment. This difference was lower for stem diameter (Figure 8B), whose largest value was of $1.36 \mathrm{~mm}$ when soil moisture level was of $31.8 \%$. The root central cylinder largest diameter was of $0.79 \mathrm{~mm}$ and this was verified when soil moisture was of $32 \%$ of its maximum water retention capacity.

The low availability of water in the soil is a limiting factor for plant growth in several parts of the world. In the Northeastern region, this is a severe factor, mainly during the low pluviosity periods which take place most of the years, causing considerable reductions in plant productivity
(LECHINOSKI et al., 2007). So, to know the characteristics of the development of the different organs of $M$. urundeuva under variable levels of water availability in the soil is useful for reforestation programs and the development of efficacious management strategies for the preservation of this species of high social and economic value.

\section{CONCLUSION}

The increasing reduction of the water level in the soil caused a reduction in the number of leaves, in the leaf area, and in the thickness of the leaflet, in the number of stomata in the leaf and in the cotyledon, the root length and the root central cylinder diameter of $M$. urundeuva seedlings. On the other hand, stem length, cotyledon length, width, and thickness of the cotyledon were not modified by the availability of water in the soil. 
RESUMO: Myracrodruon urundeuva Fr. All. é uma espécie medicinal da Caatinga. Este bioma apresenta períodos de grande seca, mas pouco se sabe sobre os mecanismos de tolerância destas plantas à falta de água no início do seu desenvolvimento e estabelecimento da plântula. O objetivo deste estudo foi avaliar as características morfoanatômicas de plântulas $M$. urundeuva submetidas a diferentes níveis de água no solo. Em um primeiro experimento, os diásporos foram semeados em terra coletada no local de ocorrência da espécie, em bandejas. O substrato foi umedecido com água em condições de 10 a $60 \%$ da capacidade de retenção, com intervalos de 5\%. Num segundo experimento, os diásporos foram semeados no substrato mantido umedecido a $60 \%$ da capacidade de retenção de água por 15 dias, para a total emergência das plântulas, por ser esta a condição mais favorável à espécie identificada na primeira etapa do trabalho. Após este período, as regas foram interrompidas e as mudas foram mantidas em substrato umedecido com $60 ; 30 ; 25 ; 20 ; 15$ e $10 \%$ de capacidade de retenção por mais 10 dias, ambos experimentos realizados em ambiente protegidos. Concluiu-se que redução progressiva da água disponível no solo fez diminuir o número de folhas; área foliar e espessura do folíolo; o número de estômatos da folha e no cotilédone, o comprimento da raiz e o diâmetro do cilindro central da raiz de $M$. urundeuva. Características como comprimento de caule, comprimento, largura e espessura do cotilédone não foram modificadas pela condição de estresse hídrico do ambiente.

PALAVRAS-CHAVE: Aroeira-do-sertão. Caatinga. Estresse hídrico. Planta medicinal.

\section{REFERENCES}

ALMEIDA, C. F. C. B. R.; SILVA, T. D. L.; AMORIM, E. L. C.; MAIA, M. D. S.; ALBUQUERQUE, U. P. Life strategy and chemical composition as predictors of the selection of medicinal plants from the Caatinga (Northeast Brazil). Journal of Arid Environments, v. 62, n. 1, p. 127-142, 2005. http://dx.doi.org/10.1016/j.jaridenv.2004.09.020

AZEVEDO, C. F.; BRUNO, R. L. A; QUIRINO, Z. G. M. Manual de frutos, sementes e plântulas de espécies arbóreas da Caatinga. Brasília: Editora Kiron, 2014. 189 p.

BRASIL, Ministério da Agricultura, Pecuária e Abastecimento. Instruções para análise de sementes de espécies florestais. Brasília: Secretaria Nacional de Defesa Agropecuária, Brasília: MAPA/ACS, 2013. 98p.

CARLINI, E. A.; DUARTE-ALMEIDA, J. M.; RODRIGUES, E.; TABACH, R. Antiulcer effect of the pepper trees Schinus terebinthifolius Raddi (aroeira-da-praia) and Myracrodruon urundeuva Allemão, Anacardiaceae (aroeira-do-sertão). Revista Brasileira de Farmacognosia, v. 20, n. 2, p. 140-146, 2010. http://dx.doi.org/10.1590/S0102-695X2010000200001

COSTA C. C. A.; CAMACHO, R. G. V.; MACEDO, I. D. D.; SILVA, P. C. M. D. Análise comparativa da produção de serapilheira em fragmentos arbóreos e arbustivos em área de caatinga na Flona de Açu - RN. Revista árvore, v. 34, n. 2, p. 259-265, 2010. http://dx.doi.org/10.1590/S0100-67622010000200008

DICKISON, W. C. Integrative plant anatomy. San Diego: Harcourt - Academic Press, 2000. 533p.

DUARTE, M. R.; SCHRODER, L. M.; TOLEDO, M. G.; YANO, M.; MACHADO, A. A.; MODOLO, A. K. Anatomia foliar comparada de espécies de aroeira: Myracrodruon urundeuva ALLEMÃO e Schinus terebinthifolius RADDI. Visão Acadêmica, v. 10, n. 1, p. 18-28, 2009.

http://dx.doi.org/10.5380/acd.v10i1.21315

FIGUEIRÔA, J. M.; BARBOSA, D. C. A.; SIMABUKURO, E. A. Crescimento de plantas jovens de Myracrodruon urundeuva Allemão (Anacardiaceae) sob diferentes regimes hídricos. Acta Botânica Brasileira, v. 18, n. 3, p. 573-580, 2004. http://dx.doi.org/10.1590/S0102-33062004000300015

GUERRA, M. E. C.; MEDEIROS FILHO, S.; GALLAO, M. I. Morfologia de sementes, de plântulas e da germinação de Copaifera langsdorfii. (Leguminosae - Caesalpinioideae). Cerne, v. 12, n. 4, p. 322-328, 2006. 
JAFARIAN, Z.; KARIMZADEH, A.; GHORBANI, J.; AKBERZADEH, M. Determination of ecological species groups and effective environmental factors on them. Journal of Environmental Studies, v. 37, n. 59, p. 77-88, 2011.

JOHANSEN, D. A. Plant Microtechnique. New York: McGraw-Hill Book, 1940.

KILL, L. H. P.; MARTINS, C. T. V. D.; SILVA, P. P. Morfologia e dispersão dos frutos de espécies da Caatinga ameaçadas de extinção. Embrapa Semiárido-Boletim de Pesquisa e Desenvolvimento

(INFOTECA-E), 2012.

KRAUS, J. E.; ARDUIN, M. Manual básico de métodos em morfologia vegetal. Rio de Janeiro, EDUR. 1997. $198 \mathrm{p}$.

LECHINOSKI, A.; FREITAS, J. M. N.; CASTRO, D. S.; LOBATO, A. K. S.; OLIVEIRA NETO, C. F.; CUNHA, R. L. M. Influência do estresse hídrico nos teores de proteínas e aminoácidos solúveis totais em folhas de Teca (Tectona grandis L. f.). Revista Brasileira de Biociências, v. 5, supl. 2, p. 927-929, 2007.

MARIANO, H. R. S.; BARRETO, L. S.; SILVA, A. H.; NEIVA, G. K.; AMORIM, S. M. Fotossíntese e tolerância protoplasmática foliar em Myracrodruon urundeuva Fr. All. Floresta, v. 39, n. 4, p. 853-859, 2009.

MARTINS, C. C.; PEREIRA, M. R. R.; LOPES, M. T. G. Germinação de sementes de eucalipto sob estresse hídrico e salino. Bioscience Journal, v. 30, supl. 1, p. 318-329, 2014.

MARTINS, C. C.; PEREIRA, M. R. R.; MARCHI, S. R. Germinação de sementes de Melaleuca quinquenervia em condições de estresse hídrico e salino. Planta Daninha, v. 29, n. 1, p. 1-6, 2011.

http://dx.doi.org/10.1590/S0100-83582011000100001

MCCREE, K. J.; FERNÁNDEZ, C. J. Simulation model for studyng physiological water stress responses of whole plants. Crop Science, v. 29, n. 2, p. 353-360, 1989.

https://doi.org/10.2135/cropsci1989.0011183X002900020025x

MUNNS, R. Comparative physiology of salt and water stress. Plant, Cell \& Environment, v. 25, n. 2, p. 239250, 2002. https://doi.org/10.1046/j.0016-8025.2001.00808.x

NASCIMENTO, H. H. C.; NOGUEIRA, R. J. M. C.; SILVA, E. C.; SILVA, M. A. Análise do crescimento de mudas de jatobá (Hymenaea courbaril L.) em diferentes níveis de água no solo. Revista Árvore, v. 35, n. 3, p. 617-626, 2011. http://dx.doi.org/10.1590/S0100-67622011000400005

NERY, F. C.; ALVARENGA, A. A.; JUSTO, C. F.; CASTRO, E. M.; SOUZA, G. S.; ALVES, E. Aspectos anatômicos de folhas de plantas jovens de Calophyllum brasiliense Cambess. submetidas a diferentes níveis de sombreamento. Revista Brasileira de Biociências, v. 5, n. S2, p. 129-131, 2007.

OLIVEIRA, A. M.; LINHARES, P. C. F.; MARACAJÁ, P. B.; RIBEIRO, M. C. C.; BENEDITO, C. P. Salinidade na germinação e desenvolvimento de plântulas de aroeira (Myracrodruon urundeuva Fr. All.). Caatinga, v. 20, n. 2, p. 39-42, 2007.

PAES, J. B.; MORAIS, V. D. M.; LIMA, C. R. D.; SANTOS, G. J. C. D. Resistência natural de nove madeiras do semiárido brasileiro a fungos xilófagos em simuladores de campo. Revista Árvore, v. 33, n. 3, p. 511-520, 2009. http://dx.doi.org/10.1590/S0100-67622009000300013

REICHARDT, K; TIMM, L. C. Solo, Planta e Atmosfera. Conceitos, processo e aplicações.2. Ed. Barueri-SP. Manole. 2012. 500 p.

SCALON, S. P. Q.; JEROMINE, T. S. Substratos e níveis de água no potencial germinativo de sementes de uvaia. Revista Árvore, v. 37, n. 1, p.49-58, 2013. http://dx.doi.org/10.1590/S0100-67622013000100006 
SCALON, S. P. Q.; MUSSURY, R. M.; MELLO EUZÉBIO, V. L.; KODAMA, F. M.; KISSMANN, C. Estresse hídrico no metabolismo e crescimento inicial de mudas de mutambo (Guazuma ulmifolia Lam.).

Ciência Florestal, v. 21, n. 4, p. 655-662, 2011. https://doi.org/10.5902/198050984510

SILVA, M. B. R.; FERNANDES, P. D.; DANTAS NETO, J.; NERY A. R.; RODRIGUES, L. N.; VIÉGAS R. A. Crescimento e produção do pinhão-manso irrigado com água residuária sob condições de estresse hídrico. Revista Brasileira de Engenharia Agrícola e Ambiental, v. 15, n. 6, p. 621-629, 2011.

https://doi.org/10.1590/S1415-43662011000600013

SOUSA NETO, O. N.; SILVA DIAS, N.; NETO, M. F.; LIRA, R. B.; REBOUÇAS, J. R. L. Utilização do rejeito da dessalinização da água na produção de mudas de espécies da caatinga. Revista Caatinga, v. 24, n. 4, p. 123-129, 2011.

SOUZA C. C.; OLIVEIRA, F. A. D.; SILVA, I. D. F. D.; NETO, A.; SILVA, M. Avaliação de métodos de determinação de água disponível e manejo da irrigação em solo roxo sob cultivo de algodoeiro herbáceo.

Revista Brasileira de Engenharia Agrícola e Ambiental, v. 4, n. 3, p. 338-342, 2000.

http://dx.doi.org/10.1590/S1415-43662000000300006

SOUZA, S. M.; AQUINO, L. C.; MILACH JUNIOR, A. C.; BANDEIRA, M. A.; NOBRE, M. E.; VIANA, G. S. Antiinflammatory and antiulcer properties of tannins from Myracrodruon urundeuva Allemão (Anacardiaceae) in Rodents. Phytotherapy Research, v. 21, n. 3, p. 220-225, 2007. http://dx.doi.org/10.1002/ptr.2011

TAIZ, L.; ZEIGER, E. Fisiologia vegetal. 5. ed. Porto Alegre: Artmed, 2013. 918 p. 